Vol 1, No 2 Agustus - Desember 2020

\title{
KODE ETIK PROFESI HAKIM DALAM RANGKA MEWUJUDKAN PROFESI HAKIM YANG BERINTEGRITAS
}

\author{
Mario Agusta, Chindy Oeliga Yensi Afita, Syafrinia
}

\author{
Dosen dan mahasiswa pada Fakultas Hukum Universitas Muara Bungo \\ Jl. Diponegoro No. 27 Kelurahan Cadika, Kecamatan Rimbo Tengah, \\ Kabupaten Bungo Telp/Fax (0747) 323310 Kode Pos 3721 \\ Email: umb101016@gmail.Chindyoeliga@gmail.com
}

\section{Ringkasan}

Bahwa keadilan merupakan kebutuhan pokok rohaniah setiap orang dan merupakan perekat hubungan sosial dalam bernegara. Pengadilan merupakan tiang utama dalam penegakan hukum dan keadilan serta dalam proses pembangunan peradaban bangsa. Tegaknya hukum dan keadilan serta penghormatan terhadap keluhuran nilai kemanusiaan menjadi prasyarat tegak martabat dan integritas Negara. Hakim Sebagai figur sentral dalam proses peradilan senantiasa dituntut untuk mengasah kepekaan nurani, memelihara kecerdasan moral dan meningkatkan profesionalisme dalam menegakkan hukum dan keadilan bagi masyarakat banyak. Putusan Pengadilan yang adil menjadi puncak kearifan bagi penyelesaian permasalahan hukum yang terjadi dalam kehidupan bernegara. Putusan Pengadilan yang diucapkan dengan irah-irah "Demi Keadilan Berdasarkan Ketuhanan Yang Maha Esa” menunjukkan kewajiban menegakkan keadilan yang dipertanggungjawabkan secara horizontal kepada sesama manusia dan vertikal kepada Tuhan Yang Maha Esa. Setiap hakim yang dilambangkan dalam kartika, cakra, candra, sari dan tirta merupakan cerminan perilaku Hakim harus senantiasa berlandaskan pada prinsip Ketuhanan Maha Esa, adil, bijaksana berwibawa, berbudi luhur dan jujur. Ketaqwaan kepada Tuhan Yang Maha Esa, yang melandasi prinsip-prinsip pedoman Hakim dalam bertingkah laku, bemakna pengalaman tingkah laku sesuai dengan agama dan kepercayaan masing-masing menurut dasar kemanusiaan yang adil dan beradab. Ketaqwaan tersebut akan mendorong Hakim untuk berperilaku baik dan penuh tanggung jawab sesuai tuntunan agama masing-masing. Seiring dengan keluhuran tugas dan luasnya kewenangan dalam menegakkan hukum dan keadilan, sering muncul tantangan dan godaan bagi para Hakim. Untuk itu, Pedoman Perilaku Hakim merupakan konsekuensi dari kewenangan yang melekat pada jabatan sebagai Hakim yang berbeda dengan warga masyarakat biasa.

\section{PENDAHULUAN}

Hukum merupakan bagian yang tidak dapat dipisahkan dari kehidupan masyarakat manusia sehingga di dalam masyarakat selalu ada sistem hukum, ada masyarakat ada norma hukum (ubi societas ibi ius). Hukum berupaya menjaga dan mengatur keseimbangan antara kepentingan atau hasrat individu yang egoistis dan kepentingan bersama agar tidak terjadi konflik. Tujuan dari kehadiran hukum justru untuk

menegakan keseimbangan perlakuan antara hak perorangan dan hak bersama. Oleh karena itu, secara hakiki hukum haruslah pasti dan adil sehingga dapat berfungsi sebagaimana mestinya.

Hakim berasal dari kata hakama-yahkumu-haakiman yang artinya dengan qodhi yang berasal dari 
kata qodiya-yaqdiyu-qoodi yang artinya memutus. Sedangkan menurut bahasa adalah orang yang bijaksana atau orang yang memutuskan perkara atau menetapkanya. Adapun pengertian menurut syara' hakim yaitu orang diangkat oleh kepala Negara untuk menjadi hakim dalam menyelesaikan gugatan, perselisihan-perselisihan dalam bidang hukum perdata oleh karena penguasa sendiri tidak dapat menyelesaikan tugas peradilan.

Pengadilan yang mandiri, netral (tidak memihak), kompeten, transparan, akuntabel dan berwibawa, yang mampu menegakkan wibawa hukum, pengayoman hukum, kepastian hukum dan keadilan merupakan conditio sine qua non atau persyaratan mutlak dalam sebuah negara yang berdasarkan hukum. Tegaknya hukum dan keadilan serta penghormatan terhadap keluhuran nilai kemanusiaan menjadi prasyarat tegaknya martabat dan integritas Negara.

Hakim sebagai aktor utama atau figure sentral dalam proses peradilan senantiasa dituntut untuk mengasah kepekaan nurani, memelihara integritas, kecerdasan moral dan meningkatkan profesionalisme dalam

menegakkan hukum dan keadilan bagi rakyat banyak. Semua Tugas dan wewenang hakim haruslah di laksanakan sesuai dasar penagakan hukum, kebenaran dan keadilan tanpa pandang bulu dan tidak membedabedakan seperti dalam Lafal sumpah seorang Hakim.

Putusan pengadilan yang diucapkan dengan irah-irah "Demi Keadilan berdasarkan Ketuhanan Yang Maha Esa" akan menjadi pertanggungjawaban besar hakim kepada Manusia dan Tuhan Yang Maha Esa.

Berdasarkan wewenang dan tugasnya sebagai pelaku utama fungsi pengadilan, maka sikap hakim yang dilambangkan dalam kartika, cakra, candra, sari, dan tirta itu merupakan cerminan perilaku hakim yang harus senantiasa diimplementasikan dan direalisasikan oleh semua hakim dalam sikap dan perilaku hakim yang berlandaskan pada prinsip Ketuhanan Yang Maha Esa, adil, bijaksana dan berwibawa, berbudi luhur, dan jujur, Taqwa kepada Tuhan Yang Maha Esa serta melandasi prinsipprinsip kode etik Hakim dan pedoman perilaku hakim ini bermakna pengamalan tingkah laku sesuai agama dan kepercayaan masing-masing menurut dasar kemanusiaan yang adil dan beradab.

\section{PERMASALAHAN}

Bagaimana sebaiknya kode etik perilaku hakim untuk mewujudkan hakim yang berintegritas?

\section{PEMBAHASAN}

Kode Etik Profesi Hakim ialah aturan tertulis yang harus dipedomani oleh setiap Hakim Indonesia dalam melaksanakan tugas profesi scbagai Hakim, pedoman Tingkah laku (Code of Conduct) Hakim ialah penjabaran dari kode etik profesi Hakim yang menjadi pedoman bagi Hakim Indonesia, baik dalam menjalankan tugas profesinya untuk mewujudkan keadilan dan kebenaran maupun dalam pergaulan sebagai anggota masyarakat yang harus dapat memberikan contoh dan suri tauladan dalam kepatuhan dan ketaatan kepada hukum.

1. Komisi Kehormatan profesi Hakim ialah komisi yang dibentuk oleh Pengurus Pusat IKAHI dan Pengurus Daerah IKAHI untuk memantau, memeriksa, membina, dan merekomendasikan tingkah laku hakim yang melanggar atau 
Vol 1, No 2 Agustus - Desember 2020

Profesi.

2. Azas Peradilan yang baik ialah prinsip-prmsip dasar yang harus dijunjung tinggi oleh Hakim dalam melaksanakan tugasnya untuk mewujudkan peradilan yang mandiri sesuai dengan aturan dasar berdasarkan ketentuan yang ada.

Kode Etik Profesi Hakim mempunyai maksud dan tujuan :

1. Sebagai alat :

a. Pembinaan dan pembentukan karakter Hakim

b. Pengawasan tingkah laku Hakim

Sifat Hakim tercermin dalam lambang Hakim yang dikenal dengan "Panca Dharma Hakim" :

1. Kartika, yaitu memiliki sifat percaya dan takwa kepada Tuhan Yang Maha Esa, sesuai dengan agama dan kepercayaan masing-masing menurut dasar kemanusiaan yang adil dan beradab.

2. Cakra, yaitu sifat mampu memusnahkan segala kebathilan, kezaliman dan ketidakadilan.

3. Candra,. yaitu memiliki sifat bijaksana dan berwibawa.

4. Sari, yaitu berbudi luhur dan berkelakuan tidak tercela.

5. Tirta, yaitu sifat jujur. Pasal 4

Sikap Hakim

Setiap Hakim Indonesia mempunyai pegangan tingkah laku yang harus dipedomaninya:

A. Dalam persidangan :

1. Bersikap dan bertindak menurut garis-garis yang ditentukan dalam Hukum Acara yang berlaku, dengan memperhatikan azas-azas peradilan yang baik, yaitu :

a. Menjunjung tinggi hak seseorang untuk mendapat putusan (right to a decision) a. Kontrol sosial

b. Pencegah campur tangan ekstra judicial

c. Pencegah timbulnya

kesalah pahaman dan konflik

antar sesama anggota dan

antara anggota dengan

masyarakat.

3. Memberikan jaminan peningkatan moralitas Hakim dan kemandirian fungsional bagi Hakim.

4. Menumbuhkan kepercayaan masyarakat pada lembaga peradilan.

dimana setiap orang berhak untuk inengajukan perkara dan dilarang menolak untuk mengadilinya

b. Semua pihak yang berperkara berhak atas kesempatan dan perlakuan yang sama untuk didengar, diberikan kesempatan untuk membela diri, mengajuan bukti -bukti serta memperoleh informasi dalam proses pemeriksaan (a fair hearing).

c. Putusan dijatuhkan secara obyektif tanpa dicemari oleh kepentingan pribadi atau pihak lain (no bias) dengan menjunjung tinggi prinsip (nemo judex in resud)

Perilaku hakim yang sesuai seharusnya:

1. Berperilaku Adil

Adil bermakna menempatkan sesuatu pada tempatnya dan memberikan yang menjadi haknya, yang didasarkan pada suatu prinsip bahwa semua orang sama kedudukannya di depan hukum. Dengan demikian, tuntutan yang paling mendasar dari keadilan adalah memberikan perlakuan dan memberi kesempatan yang sama (equality and fairness) terhadap setiap orang.

\section{Berperilaku Jujur}

Kejujuran bermakna dapat dan berani 
menyatakan bahwa yang benar adalah benar dan yang salah adalah salah. Kejujuran mendorong terbentuknya pribadi yang kuat dan membangkitkan kesadaran akan hakekat yang hak dan yang batil.

yang hidup dalam masyarakat baik norma-norma hukum, norma-norma keagamaan, kebiasan-kebiasan maupun kesusilaan dengan memperhatikan situasi dan kondisi pada saat itu, serta mampu memperhitungkan akibat dari tindakannya.

\section{Bersikap Mandiri}

Mandiri bermakna mampu bertindak sendiri tanpa bantuan pihak lain, bebas dari campur tangan siapapun dan bebas dari pengaruh apapun.

Sikap mandiri mendorong terbentuknya perilaku Hakim yang tangguh, berpegang teguh pada prinsip dan keyakinan atas kebenaran sesuai tuntutan moral dan ketentuan hukum yang berlaku.

\section{Berintegritas Tinggi}

Integritas bermakna sikap dan kepribadian yang utuh, berwibawa, jujur dan tidak tergoyahkan. Integritas tinggi pada hakekatnya terwujud pada sikap setia dan tangguh berpegang pada nilai-nilai atau norma-norma yang berlaku dalam melaksanakan tugas.

Integritas tinggi akan mendorong terbentuknya pribadi yang berani menolak

godaan dan segala bentuk intervensi, dengan mengedepankan tuntutan hati nurani untuk menegakkan kebenaran dan keadilan serta selalu berusaha melakukan tugas dengan cara-cara terbaik untuk mencapai tujuan terbaik.

kesempurnaan dan terhindar dari setiap bentuk keangkuhan.

\section{Berperilaku Arif Dan Bijaksana}

Arif dan bijaksana bermakna mampu bertindak sesuai dengan norma-norma

\section{Bertanggungjawab}

Bertanggungjawab bermakna kesediaan untuk melaksanakan sebaik-baiknya segala sesuatu yang menjadi wewenang dan tugasnya, serta memiliki keberanian untuk menanggung segala akibat atas pelaksanaan wewenang dan tugasnya tersebut.

\section{Menjunjung Tinggi Harga Diri}

Harga diri bermakna bahwa pada diri manusia melekat martabat dan kehormatan yang harus dipertahankan dan dijunjung tinggi oleh setiap orang. Prinsip menjunjung tinggi harga diri, khususnya Hakim, akan mendorong dan membentuk pribadi yang kuat dan tangguh, sehingga terbentuk pribadi yang senantiasa menjaga kehormatan dan martabat sebagai aparatur Peradilan.

\section{Berdisiplin Tinggi}

Disiplin bermakna ketaatan pada norma-norma atau kaidah-kaidah yang diyakini sebagai panggilan luhur untuk mengemban amanah serta kepercayaan masyarakat pencari keadilan.

Disiplin tinggi akan mendorong terbentuknya pribadi yang tertib di dalam melaksanakan tugas, ikhlas dalam pengabdian dan berusaha untuk menjadi teladan dalam lingkungannya, serta tidak menyalahgunakan amanah yang dipercayakan kepadanya.

\section{Berperilaku Rendah Hati}

Rendah hati bermakna kesadaran akan keterbatasan kemampuan diri, jauh dari Rendah hati akan mendorong terbentuknya sikap realistis, mau membuka diri untuk terus belajar, 
Vol 1, No 2 Agustus - Desember 2020

menumbuh kembangkan sikap tenggang rasa, serta mewujudkan kesederhanaan, penuh rasa syukur dan ikhlas di dalam mengemban tugas.

10. Bersikap Profesional

Profesional bermakna suatu sikap moral yang dilandasi oleh tekad untuk melaksanakan pekerjaan yang dipilihnya dengan kesungguhan, yang didukung oleh keahlian atas dasar pengetahuan, keterampilan dan wawasan luas.

Sikap profesional akan mendorong terbentuknya pribadi yang senantiasa menjaga dan mempertahankan mutu pekerjaan, serta berusaha untuk meningkatkan pengetahuan dan kinerja, sehingga tercapai setinggi-tingginya mutu hasil pekerjaan, efektif dan efisien.

\section{IV.KESIMPULAN}

1. Setiap Pimpinan Pengadilan harus berupaya sungguh-sungguh untuk memastikan agar Hakim di dalam lingkungannya mematuhi Pedoman Perilaku Hakim ini.

2. Pelanggaran terhadap Pedoman ini 1.1 (2020).

\begin{abstract}
menentukan sanksi yang layak dijatuhkan, harus dipertimbangkan faktor-faktor yang berkaitan dengan pelanggaran, yaitu latar belakang, tingkat keseriusan, dan akibat dari pelanggaran tersebut terhadap lembaga peradilan ataupun pihak lain.
\end{abstract}

\section{DAFTAR PUSTAKA:}

\section{BUKU:}

Wajdi Farid, Etika Profesi Hukum, 2018, Sinar Grafika, Jakarta.

Erlita Seprika, Etika Profesi Hukum, 2019, Refika, Jakarta.

Suparman Marzuki, 208, Etika dak Profesi Hukum, Sinar Grafika, Jakarta.

\section{JURNAL :}

Khaidir, Khaidir. "Analisis Yuridis Pembalikan Beban Pembuktian Pada Tindak Pidana Korupsi." RIO LAW JURNAL 1.1 (2020).

Sari, Nirmala. "Pengangkatan Pegawai Negeri Sipil Dalam Jabatan Struktural." Rio Law Jurnal 